\title{
Performance assessment and the factors inhibiting the performance of Buddhist education teachers in the teaching duties
}

\author{
Hesti Sadtyadi \\ Sekolah Tinggi Agama Buddha Negeri Raden Wijaya \\ Jl. Kantil Bulusulur, Wonogiri, Central Java 57615, Indonesia \\ E-mail: 15hestisadtyadi@gmail.com
}

Submitted: 09 November 2018 | Revised: 27 November 2018 | Accepted: 27 November 2018

\begin{abstract}
This research aims to examine the components and inhibiting factors of the teacher's work performance in the teaching assignments of Buddhist education teachers. The author believes that the theoretical, as well as the practical problems of Buddhist education teachers, can be solved by examining its components and the inhibiting factors. This research was developmental research that begins by compiling the component of performance instrument and the inhibiting factors instrument through Exploratory Factor Analysis (EFA) and Confirmatory Factor Analysis (CFA). The data were then analyzed through regression analysis. The subjects of research were Buddhist education teachers in Central Java, Indonesia. The results of the research show the values of Anti-image $>0.5$ for 7 indicators. Meanwhile, the loading factor was bigger than 0.5 for each component. The model had RMSEA $\leq 0.05$, Chi-Square $\left(\mathrm{X}^{2}\right)>0.05, \mathrm{P}=0.55$, the GFI was 0.97, which means the model was fit. The teaching performance components of Buddhist education teacher include planning the learning program, implementing the learning program, and evaluating the learning program. The inhibiting factors of the teacher's performance are the additional tasks, the classroom atmosphere, conflict, and work pressure. This research has proved that the inhibiting factors have a negative impact on the teaching performance of Buddhist education teachers.
\end{abstract}

Keywords: teacher's performance, inbibiting factors, teaching duties

\section{Introduction}

Teacher takes important roles to establish a good quality of education. Other educational instruments, such as policy, curriculum, learning facilities, or educational technology, were just the supporting devices that will not work properly if the teacher unable to implement their competencies in the classroom. It means the management of the teacher's performance, which contains the elucidation of the teacher's role and responsibilities in the learning activities, becomes the decisive element that determines the teacher's excellence.

The manifestation of teacher's excellence in managing education, as one of the indicators of the teacher's work performance, has been depicted in the study of Suryadarma, Suryahadi, and Sumarto (2005, p. 8). The results of their study upheld the teacher's posi- tion in influencing the students' progress. Moreover, they also stated that the teacher's position is more important than other factors, for instance, the socioeconomic status and school environment. Their study is supported by the research of Amin and Khan (2009) that showed the importance of the teacher as the key in the education system.

Nevertheless, in particular cases, teacher seems hard to give a maximum impact along with their responsibilities. Sudarwan (2002, p. 168) explains that teachers have not been able to demonstrate their work performance adequately. His research shows that the teacher's performance is not at the optimum level. This is proven by the data of student graduation of 2016/2017 published by the Ministry of Education and Culture (2017), revealing that the average of students drop out is about $1.68 \%$. The data show that, to a certain degree, the 
teacher's work performance has not been optimized in motivating students to study at any level of formal education. The author also believes that these data reflect the current condition of the teachers' performance.

Based on the results of previous research regarding the development of performance instruments for elementary school teachers which was conducted by Sadtyadi and Kartowagiran (2014), the author divided the teachers' performance into two components: the teacher's main tasks and the teacher's functions. These components consist of teaching assignment, educating, guiding, training, and evaluating. Teacher's performance is the result of the works of teachers based on the implementation of their competency and the component of assessment in the form of the main tasks and functions of the teacher.

Considering teachers' the main tasks and functions, the author argues that the performance of Buddhist education teachers is necessary to be assessed to reveal the current condition of their performance level. The research of Sadtyadi (2016), which evaluated the performance of Buddhist education teachers by applying the Teacher Performance Standard model of Stronge and Hindman, has shown the sufficiency of teacher performance based on the evaluation of learning planning, learning implementation, and learning assessment of the teacher. Sadtyadi also suggested assessing the performance of Buddhist education teacher based on the implementation of teachers' performance components.

In terms of performance appraisal conducted by direct assessment to the aspects of teaching assignment, it can afford a self-evaluation for the teacher. Especially if in the assessment process, the teachers are involved in providing self-assessment as the part of selfcriticism, self-improvement, and self-evaluation. The process of performance appraisal should not be concerned only to the outcomes, but rather to the effects or the transformation resulted from the process of teacher development. The effects and transformations based on the performance appraisal are expected to be a consideration for the teachers as a fundamental recommendation to elevate their work performance.
The transformation of teacher's work performance can be stimulated by the teacher's introspection of records of accomplishment and various aspects of performance that should be executed. Performance appraisals can also be implemented through peer review or discussion with superiors or colleagues. Precisely, the performance appraisal through peer review and discussion is important as self-assessment and as a medium to evaluate generally the teacher's work performance.

The appraisal of teacher's work performance, particularly for Buddhist education teachers, has a specific characteristic that lies in a number of standards that generally cannot be fulfilled by the teacher, especially related to the standards of infrastructure that are adjacent to the implementation of teaching assignment. The Buddhist education has not entirely used a proper classroom in accordance with the learning schedule. Based on the author's observation, a classroom has been provided for studying Buddhist, but it is not implicitly available. Another problem of Buddhist education is the lack of teaching textbook, because the textbooks and also the teaching material are not sold freely. The textbooks of Buddhist education are sold through certain institutions. In the bookstores, the offered Buddhist books take a specific topic such as Dhamma or meditation, which are commonly used for public readers, and not for Buddhist education students.

Based on the afore-mentioned description, this research is aimed at examining the construction and the inhibiting factors of the Buddhist education teachers' work performance. Theoretically, the assessment of teacher's work performance will be convenient to do by examining its construction. Meanwhile, by knowing the inhibiting factors, the problems of teacher's work performance are easy to overcome, thus, the teacher's performance can be elevated. Practically, this research also tries to arrange the construction as well as the components of teacher's work performance to support the process of teacher improvements, and a reference for policymaking related to improving teacher performance, especially Buddhist education teachers. 


\section{Method}

In order to examine the components and inhibiting factors of the teacher's work performance, the methodological frameworks of developmental research model (Borg \& Gall, 1983, p. 772) and the Mardapi's developmental stage (Mardapi, 2008, p. 108), were employed as the research method. The subjects of the research were Buddhist education teachers in Central Java Province, Indonesia. In the developmental stage, 52 Buddhist education teachers, consisting of four teachers from Wonogiri Regency, 26 teachers from Semarang Regency, and also 22 teachers from Temanggung Regency, were participated.

The preliminary research was conducted through the literature review, which was used to obtain the related theories and previous research that could be used to support the analysis of research. The further stage was the initial research to adjust the various theories and results of existing research studies, so it would afford a complete study. The initial draft was developed from December 2014 to February 2015. Furthermore, the implementation of the instrument was conducted from August to November 2015, and February to June 2016. At the interval time, deep evaluation, improvements, and readjustments to the instruments were conducted.

The instrument was developed based on the components of teacher's work performance, which are derived from the components of the main tasks and functions of the teacher, specifically the teaching task components. The developed instrument was a nontest instrument, in the form of questionnaires for self-assessment and peer assessment. The developed instrument was generated by considering several points such as instrument specifications based on adequate theoretical studies, grids channel of instruments containing dimensions or components and indicators as well as the number of items from the indicator. The next step was writing instruments along with scaling and scoring systems. Then the review or study of the instrument was carried out. A small-scale trial had been conducted to determine the validity and reliability of the instruments. If the quality of the developed instrument reached the expected cri- teria, it can be measured against the teacher's work performance. The final step was the interpretation of the measurement to examine the components and the inhibiting factors of teacher's work performance.

\section{Subject and Setting}

The subjects of the initial study conducted at the beginning of December 2014 until February 2015 were Buddhist education teachers and the implementation of the adjusted and developed instrument was conducted from August to November 2015. The first-stage testing was conducted to 52 teachers as the respondents, and the second-stage testing was conducted to 97 teachers as the respondents, carried out during February-June 2016. The research was conducted in three regencies: Wonogiri, Temanggung, and also Semarang. The three regencies are located in Central Java, Indonesia.

Data, Instrument, and Data Collecting Technique

The data used in this study were mostly quantitative data. The data were collected comprehensively, starting from the instrument arrangement until the product of the instrument and its use, so that the data gained were from religious education teachers, especially Buddhist education teachers. The data were categorized based on arranged instruments: performance assessment instrument and teachers' performance inhibiting factors instrument. The data gained at the initial stage were qualitative data in the form of input from the discussion result and literature study. In addition, the data on the first-stage testing and the second-stage testing were data collected from the use of the instruments of performance assessment and its inhibiting factors, and are in the form of quantitative data.

\section{Data Analysis Technique}

The mixed analysis, consisted of qualitative and quantitative approaches, was used as a data analysis technique. The data of Focus Group Discussion were analyzed qualitatively. Meanwhile, the data regarding the developed instrument were analyzed quantita- 
tively. Based on the instruments used, the data were analyzed by factor analysis to obtain appropriate instruments that can be used to compile the instrument of teacher' work performance. The factor analysis was employed through Exploratory Factor Analysis. In the second stage of analysis, the Lisrel program by using Confirmatory Factor Analysis (CFA) for the whole model was implemented to support the analysis. The standard of fitness of the instrument used the criteria proposed by Basuki (2004, p. 12) and Ghozali (2005, p. $325)$, with the Chi-Square $\left(X^{2}\right)>0.05$, model fit, RMSEA 0.05 indicating the model fit, 0.05 $<$ RMSEA $\leq 0.08$ shows a reasonable model, $0.08<$ RMSEA $\leq 0.1$, shows sufficient model or (mediocre), and RMSEA $>0.1$ indicates a poor fit model. GFI value 90.9 is a fitness model. The drafting model began with factor analysis and validity and reliability tests.

Besides, statistical analysis with a qualitative descriptive approach was also employed to analyze the suggestions from Focus Group Discussion and interpret the values from quantitative to qualitative data, so that developed instrument became more valuable. The level of teacher's work performance criteria was determined by a relative scale based on the teacher's qualification. The qualification of teacher's work performance was derived from the literature review, expert suggestions, and author's observation. The qualification can be divided into five categories, such as very good performance, better performance, perform adequately, poor performance, and very poor performance. This technique was also used to conceive the actual performance of the teacher in accordance with the learning objectives, learning methods, and teachers' suitability in the learning process.

\section{Instrument Validity and Reliability}

Content validity refers to the suitability and readability of the content of the developed instrument with the existing material. The content validity was derived from consideration of fellow researchers, linguist, and Buddhist education teachers. The content validity test aimed to test the readability of the concept and the suitability with the learning objectives.
A factor analysis was employed to test the construct validity of the instrument and find the appropriate composition of the items. As proposed by Kim and Mueller (1986, p. 70), Coakes and Steed (1996, p. 124), Hair, Anderson, Tatham, and Black (2006, p. 129), and Azwar (2013, p. 86), the basic criteria in Stage I refer to the validity of the item and factor loading for each indicator. The items should have a factor loading bigger than 0.3 to be considered for review and revision. Further, in Stage II, the item was tested using CFA, and then the valid items were retained.

The construct validity test was conducted by Exploratory Factor Analysis test with the SPSS program 15.0 for Windows. This program used to determine the correlation between the items, the result by varimax rotation technique, and the factor loading and common factor variance. The reliability test was employed the Cronbach Alpha criteria, with 0.7 for reliability values.

\section{Findings and Discussion}

\section{The Result of the Initial Stage}

The initial stage was begun with the literature review to find the previous research and theoretical and empirical studies. Furthermore, the interdisciplinary focus group discussions from the expert of education, linguistics, religious studies, and the Buddhist education teachers were held to obtain the empirical data and recommendations. They participated to measure the validity, reliability, and readability the initial draft of the developed instrument. The empirical data and recommendation were used to revise the initial draft.

The first FGD was designed to examine the content validation that was conducted by analyzing several points such as the texts, language, as well as the suitability with the learning objectives besides of compared with theoretical studies of the instruments. The results of FGD generated the instruments that acceptably with the laws and regulations and the Technical Guidelines for Implementing Teacher's Functional Position and Credit Numbers. In order to examine the inhibiting factors of teacher's work performance, the developed instrument was conducted by con- 
sidering Maslach Burnout Inventory (Maslach, Jackson, \& Leiter, 1997). Meanwhile, Aiken's $\mathrm{V}$ formula also was used to measure the validation. The calculation of content-validitycoefficient was assessed by three Buddhist education teachers, with the results of the test can be concluded that all instruments have high coefficient values, 0.75 to 1 . Thus, with limited improvements, the initial design of the developed instrument can be maintained in the next stage.

\section{Test Results of Stage I}

On Stage I, the data were analyzed by considering the factor analysis. The confirmatory approach of the extraction method and the maximum likelihood showed that the instrument was valid and reliable, which was indicated by the values of factor load of each instrument is more than 0.5 that means the items are possible to be used. By noting on the metric component rotated value, which generated a value greater than 0.5 , the author indicated the items on the instrument form a certain component in the teaching assignment of Buddhist education teachers. It also forms a component of performance inhibiting instruments. The result of KMO was 0.596, which means that the $\mathrm{KMO}$ was miserable.

Table 1 shows the result of the exploratory analysis that shows the work performance of Buddhist education teachers in teaching assignments, includes the teaching programs, the implementation of learning programs, and the evaluation of learning programs. Meanwhile, the components of the inhibiting factors include additional tasks, class atmosphere, conflict, and work pressure.

Table 1. The result of exploratory analysis in anti image

\begin{tabular}{lcc}
\hline Indicators & Test I & Test II \\
\hline Planning & $.642(\mathrm{a})$ & $.804(\mathrm{a})$ \\
Implementing & $.607(\mathrm{a})$ & $.714(\mathrm{a})$ \\
Evaluating & $.553(\mathrm{a})$ & $.659(\mathrm{a})$ \\
Additional Task & $.619(\mathrm{a})$ & $.687(\mathrm{a})$ \\
Classroom & $.541(\mathrm{a})$ & $.647(\mathrm{a})$ \\
Conflict & $.566(\mathrm{a})$ & $.713(\mathrm{a})$ \\
Workpressure & $.658(\mathrm{a})$ & $.759(\mathrm{a})$ \\
\hline
\end{tabular}

Source: The author's processed data
The Development of the Instrument of Work Performance and Its Inbibiting Factors

The second FGD was the advanced of the previous stage for content validation. The participant of the second FGD reviewed the instruments from the various provisions of the instruments arrangement. The Aiken's V formula was also employed to calculate the content-validity-coefficient of each item in the developed instrument. The test had indicated that all instruments had coefficient values of 0.85 to 1 , which means the items had high coefficient values, thus, the instrument was ready to be used.

The result of the second FGD showed that the teacher's work performance in teaching assignments could be prepared by designing an appropriate teaching program, implementing the learning program, and evaluating the learning program. Whereas, the inhibiting factors of teacher's work performance are the additional tasks, classroom atmosphere, the conflict, and the work pressure in accordance with the previous factor analysis.

\section{The Results of Stage II}

\section{Analysis of Validity, Reliability and GOF of the Developed Instrument}

In Stage II, the author held a larger test than the previous stage by analyzing the teacher's work performance of 97 teachers from Wonogiri, Semarang and Temanggung regencies, Central Java, Indonesia. The analysis shows that the data had a normal distribution. In Stage II, the author reiterated the same analysis on the previous stage by testing the validity and reliability of the developed instruments. Several suggestions on Stage II had highlighted same points that the teacher's work performance of the Buddhist education teachers could be explained by three components: planning the teaching programs, implementing learning programs, and evaluating the learning programs. Whereas, the inhibiting factor of the teacher's work performance can be explained into four indicators: the additional tasks, classroom atmosphere, the conflicts, and the work pressure. The model has similarities from the Stage I. The value of Anti-image test was above 0.5 . The analysis of 
the Rotated Component Matrix generated 7 indicators. Based on the value of each Antiimage, which had a value of more than 0.5 and the loading factor value for each component was more than 0.5 , had indicated that each item had no double dimensions.

Table 2. The result of exploratory analysis

\begin{tabular}{lcc}
\hline & Test I & Test II \\
\cline { 2 - 3 } & \multicolumn{2}{c}{ Components } \\
\hline Number & 1 & 1 \\
Planning & 0.708267 & 0.792478 \\
Implementing & 0.732193 & 0.839202 \\
Evaluating & 0.819713 & 0.883535 \\
& 2 & 2 \\
Additional task & 0.739685 & 0.829552 \\
Classroom & 0.614886 & 0.540466 \\
Conflict & 0.720257 & 0.804357 \\
Work pressure & 0.545565 & 0.651139 \\
\hline
\end{tabular}

Source : The author's processed data

The value of the Cronbach Alpha's showed the reliability value of the developed instrument was 0.8. It means the developed instrument was reliable. Likewise, the value of inhibiting factor instruments has the Cronbach's Alpha 0.7, which indicated that the developed instrument was reliable. The value of $\mathrm{KMO}$ was bigger than 0.5 , which equal to 0.710 . This value indicated that the developed instrument could be enhanced in the next stages. By using EFA, it could be explained that the loading factors from each indicator are form two components. The first component was called the performance component, composing of three indicators of the teaching assignment components. The second component was the performance barrier, which consists of four indicators that compose from the component of performance inhibiting component.

The CFA analyzed seven indicators that composed from the component of the work performance and the inhibiting factor, with the highly significant loading factor. Thus, the teacher's work performance (Kinerja) could be arranged by using three indicators: the teaching programs (Ajar 1$)$, the implementation of learning programs (Ajar2), and the evaluation of learning programs (Ajar3). Whereas, four indicators could explain the inhibiting factors: the additional tasks (TGSTAM), the classroom atmosphere (Kelas), the conflict (Konflik), and the work pressure (TEKKERJA). Overall, the results of the Stage I was similar with the Stage II.

Confirmatory Factor Analysis (CFA) was employed for the entirety model. The criteria of a fit model showed that the model has RMSEA $\leq 0.05$, the Chi-Square $\left(\mathrm{X}^{2}\right)>$ $0.05, \mathrm{P}=0.55$, which all indicated that the model was fit. Likewise, the value of GFI was equal to 0.97 , which indicated that the model was fit.

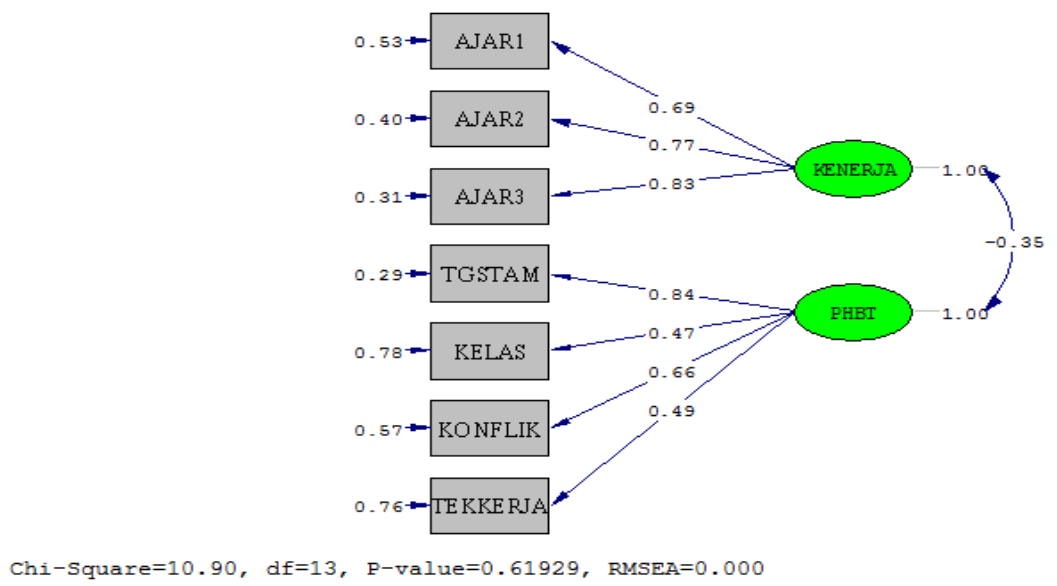

Figure 1. The result of Confirmatory Factor Analysis (CFA) 
The Result of Implementation Stage

Based on the application of performance appraisal instruments and inhibiting factors, it can be illustrated that the Buddhist education teachers, in achieving performance, have significant obstacles, which are around $40 \%$, while $14 \%$, which have few obstacles. The tabulation of the inhibiting factors is illustrated in Figure 2.

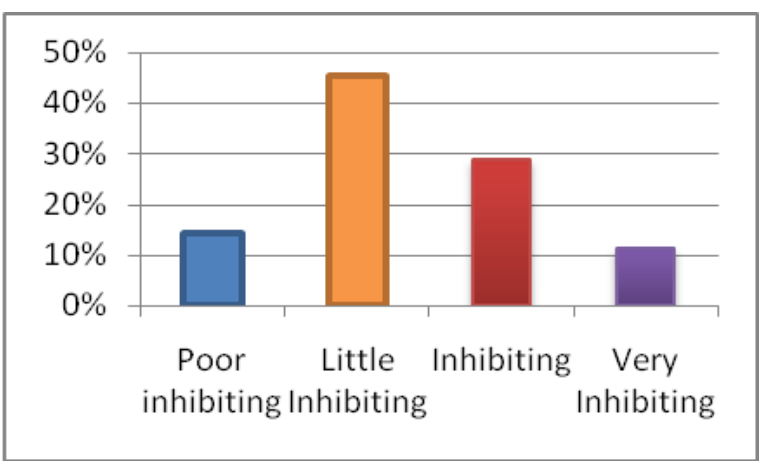

Figure 2. The tabulation of the inhibiting performance factors of Buddhist education teachers

Based on the teaching performance instrument, the performance of Buddhist education teachers is tabulated in Figure 3. The teacher who has good teaching performance ranged from $31 \%$, the teachers with less performance ranged from $31 \%$, while the teacher with the poor performance was about 37 $\%$. These results show that there are inhibiting factors in the work performance of Buddhist education teachers.

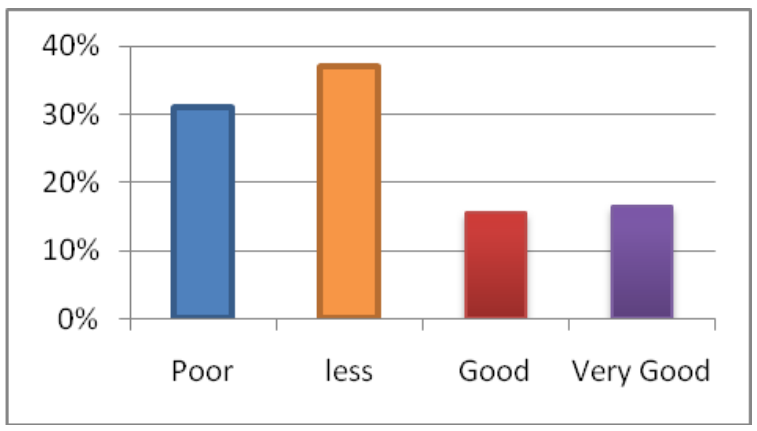

Figure 3. The level of teacher's work performance of Buddhist education teachers

The inhibiting factors of the Buddhist education teachers were analyzed using the regression analysis. The analysis showed the influence of the inhibiting factors on the perfor- mance of Buddhist education teachers. By using Lisrel program, through the Structural Equation Model (SEM) analysis technique, the numbers of the influence of the inhibiting factors on teacher performance is -0.28 with the $\mathrm{t}$-test indicated that the value of the $\mathrm{t}$ count was greater than the t-table. It means that the regression coefficient was significant, thus, it can be explained that there was a negative influence of the inhibiting factors on the performance of Buddhist education teachers.

From the afore-mentioned description, it is indicated that the performance of Buddhist education teachers in teaching assignments can be prepared through teaching assignment indicators, which include planning the teaching programs, implementing the learning programs, and follow-up the learning programs. Meanwhile, four indicators can explain the inhibiting factor of the teacher's work performance: the additional tasks, classroom atmosphere, the conflict, and the work pressure. The additional task generally referred to as some additional responsibilities outside of the main task area, or not in accordance with their basic competencies, such the administrative tasks. The problem of additional task commonly can be found in the primary school teachers in which the school structure does not have administrative staff. Therefore, the teachers have many additional tasks that potentially can hinder their work performance. The second component is the classroom atmosphere that relates to the infrastructure used by the teacher in the learning process. There are still the shortcomings relate to the supporting media or infrastructure to implement the Buddhist education in the school. The conflict generates a negatively affects for the teacher's work performance. It relates to the importance of communication, work relations, and internal problems of the teachers. Moreover, the component of work pressure relates to many pressures and obstacles that have been faced by the teachers. Some of the Buddhist education teachers teach far away from their hometown. In sum, those inhibiting components can be a barrier to the performance of Buddhist education teachers. 


\section{Conclusion and Suggestions}

The components of the teacher's work performance of Buddhist education teachers consist of planning the teaching programs, implementing learning programs, and evaluating learning programs. Meanwhile, the inhibiting factors of the teacher's work performance are the additional tasks, the classroom atmosphere, the conflict, and the work pressure. Those inhibiting factors can negatively affect the work performance of Buddhist education teachers. In order to overcome as well as improve the teacher's work performance, the teacher must be able to reduce the inhibiting factors by noticing each dimension of the inhibitor indicators.

\section{References}

Amin, H. U., \& Khan, A. R. (2009). Acquiring knowledge for evaluation of teachers' performance in higher education - using a questionnaire. (IJCSIS) International Journal of Computer Science and Information Security (Vol. 2).

Azwar, S. (2013). Penyusunan skala psikologi (2nd ed.). Yogyakarta: Pustaka Pelajar.

Basuki, H. (2004). Analisis faktor konfirmatori (Confirmatory Factor Analysis) dalam materi pelatihan SEM (Structural Equation Modeling) angkatan IV, Surabaya. Surabaya: Lembaga Penelitian Universitas Airlangga.

Borg, W. R., \& Gall, M. D. (1983). Educational research: An introduction (4th ed.). New York, NY: Longman.

Coakes, S. J., \& Steed, L. G. (1996). SPSS version 14.0 for Windows: Analysis without anguish. Melbourne: Jacaranda Wiley.

Ghozali, I. (2005). Structural equation modeling: Teori, konsep, dan aplikasi dengan program Lisrel 8.80. Semarang: Badan Penerbit Universitas Diponegoro.
Hair, J. F., Anderson, R. E., Tatham, R. L., \& Black, W. C. (2006). Multivariate data analysis (6th ed.). Upper Saddle River, NJ: Prentice-Hall.

Kim, J.-O., \& Mueller, C. W. (1986). Factor analysis: Statistical methods and practical issues. London: Sage Publications.

Mardapi, D. (2008). Teknik penyusunan instrumen tes dan nontes. Yogyakarta: Mitra Cendekia.

Maslach, C., Jackson, S. E., \& Leiter, M. P. (1997). Evaluating stress: $A$ book of resources. (C. P. Zalaquett \& R. J. Wood, Eds.) (3rd ed.). Lanham, Md., \& London: The Scarecrow Press.

Ministry of Education and Culture. (2017). Ikbtisar data pendidikan tabun 2016/2017. Jakarta. Retrieved from http://publik asi.data.kemdikbud.go.id/uploadDir/isi _FC1DCA36-A9D8-4688-8E5F0FB5ED1DE869_.pdf

Sadtyadi, H. (2016). Evaluasi kinerja guru Pendidikan Agama Buddha dan alumni Prodi Dharmacarya. Wonogiri: STABN Raden Wijaya.

Sadtyadi, H., \& Kartowagiran, B. (2014). Pengembangan instrumen penilaian kinerja guru sekolah dasar berbasis tugas pokok dan fungsi. Jurnal Penelitian Dan Evaluasi Pendidikan, 18(2), 290-304. https://doi.org/10.21831/pep.v18i2.28 67

Sudarwan, D. (2002). Inovasi pendidikan dalam upaya peningkatan profesionalisme tenaga kependidikan. Bandung: Pustaka Setia.

Suryadarma, D., Suryahadi, A., \& Sumarto, S. (2005). Penentu kinerja murid sekolah dasar di Indonesia. Jakarta: Semeru, Yertas Verja. 